\title{
Production of gladiolus submitted to gibberellic acid in a protected environment ${ }^{1}$
}

\author{
Maristela Pereira Carvalho-Zanão ${ }^{2}$, Fabíola Villa ${ }^{2}$, Claudio Yuji Tsutsumi ${ }^{2}$, Natália Pereira ${ }^{3}$
}

\section{ABSTRACT}

Gladiolus is an important cut flower commercialized in Brazil, and the use of gibberellic acid $\left(\mathrm{GA}_{3}\right)$ to cultivate it in a protected environment may promote the production of high quality flower spikes. This study aimed at evaluating the production of flower spikes and corms of gladiolus ('White Friendship' cultivar) submitted to high concentrations and application methods of gibberellic acid, in a protected environment. The experimental design was randomized blocks, in a $2 \times 4$ factorial arrangement, being two application methods (foliar spraying and corm soaking) and four concentrations (0 mg L-1, $250 \mathrm{mg} \mathrm{L}^{-1}, 500 \mathrm{mg} \mathrm{L}^{-1}$ and $1,000 \mathrm{mg} \mathrm{L}^{-1}$ ) of gibberellic acid, with six replications and two plants per experimental unit. The following traits were evaluated: plant height, number of leaves per plant, marketable harvest point of flower spikes, number of florets per flower spike, flower panicle length, stem and floret diameter, corm perimeter, number of cormels per plant and production of corm fresh matter and leaf dry matter, flower spikes, corms and cormels. High concentrations of $\mathrm{GA}_{3}$ are not recommended for the production of flower spikes and corms of the gladiolus 'White Friendship' cultivar. The corm soaking application method anticipates the harvest of flower spikes and produces a higher number of cormels per plant. Regardless of the application method, the

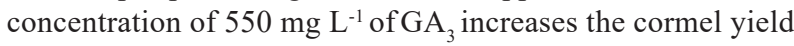
of the 'White Friendship' cultivar.

KEYWORDS: Gladiolus $x$ grandiflorus Hort; plant growth regulator; cut flower.

\section{INTRODUCTION}

The Brazilian floriculture has developed remarkably in recent years, and it is one of the most promising segments of intensive horticulture in the country. Strong growth rates of traditional production centers and the creation of new regional centers have been observed in recent years (Junqueira \& Peetz 2013).

\section{RESUMO}

Produção de gladíolo submetido a ácido giberélico em ambiente protegido

O gladíolo é uma importante flor de corte comercializada no Brasil, e a utilização de ácido giberélico $\left(\mathrm{GA}_{3}\right)$ no manejo de cultivo em ambiente protegido pode promover a produção de hastes florais de melhor qualidade. Objetivou-se avaliar a produção de hastes florais e cormos de gladíolo cv. 'White Friendship' submetido a modos de aplicação e altas concentrações de ácido giberélico, em ambiente protegido. $\mathrm{O}$ delineamento experimental foi em blocos casualizados, em esquema fatorial 2 x 4, sendo dois modos de aplicação (pulverização foliar e imersão do cormo) x quatro concentrações ( $0 \mathrm{mg} \mathrm{L}^{-1}, 250 \mathrm{mg} \mathrm{L}^{-1}, 500 \mathrm{mg} \mathrm{L}^{-1}$ e $\left.1.000 \mathrm{mg} \mathrm{L}^{-1}\right)$ de ácido giberélico, com seis repetições e duas plantas por unidade experimental. Avaliaram-se a altura da planta, número de folhas por planta, ponto de colheita comercial das hastes florais, número de floretes por haste floral, comprimento do pendão floral, diâmetro do florete e da haste floral, perímetro do cormo, número de cormilhos por planta, produção de matéria fresca do cormo e de matéria seca de folhas, haste floral, cormo e cormilhos. Altas concentrações de $\mathrm{GA}_{3}$ não são recomendadas para a produção de hastes florais e cormos de gladíolo cv. 'White Friendship'. O modo de aplicação por imersão do cormo antecipa a colheita das hastes florais e produz maior número de cormilhos por planta. Independentemente do modo de aplicação, a concentração de $550 \mathrm{mg} \mathrm{L}^{-1}$ de GA $\mathrm{G}_{3}$ incrementa a produção de cormilhos da cultivar 'White Friendship'.

PALAVRAS-CHAVE: Gladiolus $x$ grandiflorus Hort; regulador vegetal; flor de corte.

Cut flowers, such as gladiolus (Gladiolus $\mathrm{x}$ grandiflorus Hort.), are among the main products sold by the flower industry in Brazil (Benschop et al. 2010, Mushtaq et al. 2013). Gladiolus is an herbaceous plant of the Iridaceae family, with a modified stem called corm. A mother corm sprouts a new flowering corm, various cormels and a new plant which produces a spike-type inflorescence with

1. Manuscript received in Jul./2016 and accepted for publication in Dec./2016 (http://dx.doi.org/10.1590/1983-40632016v4642418).

2. Universidade Estadual do Oeste do Paraná, Centro de Ciências Agrárias, Marechal Cândido Rondon, PR, Brazil.

E-mails: maristelacarvalho@gmail.com, fvilla2003@libero.it, claudiotsutsumi@unioeste.br.

3. Universidade Estadual do Oeste do Paraná, Centro de Ciências Exatas e Tecnologias, Cascavel, PR, Brazil.

E-mail: pe.nataliaa@gmail.com. 
buds called florets, arranged on the primary steam: the rachis (Tombolato 2004, Paiva et al. 2013).

Plant growth regulators are widely used in floriculture to promote changes in plant growth and development (Miller 2012). In floriculture, the most popular plant growth regulators are the gibberellins. They efficiently induce flower formation, anticipate anthesis, and partially or totally replace cold and photoperiodic treatments required by some species to bloom (Taiz \& Zeiger 2013). This is the case for iris, hyacinth and lily (Vieira et al. 2010). They also promote cell division and consequently longer flower stems, as well as more corms and cormels per plant (Gupta \& Chakrabarty 2013, Esfahani et al. 2016).

Among the gibberellins, the gibberellic acid $\left(\mathrm{GA}_{3}\right)$ is best known for breaking the dormancy of seeds, bulbs and tubers, stimulating the flower bud production, elongating flower stems and anticipating flowering (Ramzan et al. 2014). Many of these effects have been observed in bulbous ornamental plants such as calla (Miller 2012), gladiolus (Bhujbal et al. 2014, Aier et al. 2015) and tulip (Ramzan et al. 2014).

The effect of gibberellin may vary depending on several factors inherent to the plant (species, cultivar and phenological stage), environment (light, weather conditions and period) and product concentration and application method (Kerbauy 2008, Vieira et al. 2010). However, a small number of studies have assessed different application methods along with various concentrations of $\mathrm{GA}_{3}$ for gladiolus.

The main $\mathrm{GA}_{3}$ application methods include pretreatment by soaking corms, bulbs and/or rhizomes before planting, as well as foliar spraying at different development stages (Ramzan et al. 2014). The advantage of pre-soaking is that it is easy to apply and many corms may be uniformly treated in a small container (Miller 2012). However, once treated, the substance cannot be removed from the corm. Regarding the concentrations, a range of $10-500 \mathrm{mg} \mathrm{L}^{-1}$ of GA may be used, depending on the species and application method (Vieira et al. 2010, Khan et al. 2013).

This study aimed at evaluating application methods along with high concentrations of $\mathrm{GA}_{3}$ for the production of flower spikes and corms of the 'White Friendship' gladiolus cultivar under protected environment.

\section{MATERIAL AND METHODS}

The experiment was carried out in a greenhouse

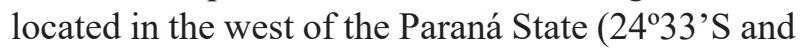

$54^{\circ} 31^{\prime} \mathrm{W}$ ), under a controlled environment, from August 2015 to January 2016. The average daily air temperature was $28.4{ }^{\circ} \mathrm{C}$ (minimum of $18.7^{\circ} \mathrm{C}$ and maximum of $32.2^{\circ} \mathrm{C}$ ).

The Gladiolus grandiflorus Hort. ('White Friendship' cultivar) was used. It is characterized by an early cycle, folded petals of white color, flowering at 63 days after planting (DAP), with new corm and cormels maturing at 154 DAP (Barbosa 2011). Second generation corms obtained from the Terra Viva Bulbos company were used. They were selected and ranked according to their average perimeter $(20-22 \mathrm{~cm})$ and weight $(64 \mathrm{~g})$. Treated corms were planted at a depth of $5 \mathrm{~cm}$, in polyethylene pots filled with $4 \mathrm{dm}^{3}$ of the Tropstrato $\mathrm{HT}^{\circledR}$ commercial substrate, which is based on pine bark, peat and expanded vermiculite.

The experimental design was randomized blocks, with two application methods (foliar spraying and corm soaking) and four concentrations $\left(0 \mathrm{mg} \mathrm{L}^{-1}, 250 \mathrm{mg} \mathrm{L}^{-1}\right.$, $500 \mathrm{mg} \mathrm{L}^{-1}$ and $1,000 \mathrm{mg} \mathrm{L}^{-1}$ ), replicated six times. Each experimental unit consisted of a pot with two plants.

The soaking of corms in a $\mathrm{GA}_{3}$ solution was performed for $15 \mathrm{~min}$. Then, the corms were shade dried for $1 \mathrm{~h}$, before planting. A commercial product (Progibb ${ }^{\circledR}$, Abbott Laboratories), containing $40 \%$ of $\mathrm{GA}_{3}$, was used in both application methods.

Foliar spraying was carried out at 15 days after emergence (DAE), between 8:00 a.m. and 9:00 a.m., when the plants had, on average, two leaves. The spray solution was amended with $1 \mathrm{~mL} \mathrm{~L}^{-1}$ of nonionic surfactant (ethoxylated sorbitan monolaurate), in order to reduce the surface tension and improve dispersion and adhesion. A knapsack sprayer with cone nozzle was used to apply about $50 \mathrm{~mL}$ of the solution per plant. During the application, the pots were separated and their surface was covered with paper towel to prevent dripping onto the substrate.

The pots were irrigated manually every day, in the morning. The substrate weighing method was used to determine the water retention capacity by mass difference, and irrigation was performed to maintain the substrate at approximately $80 \%$ of its capacity (Porto et al. 2014). The pots were irrigated until leaves turned yellow, coinciding with corm and cormel maturation. Fertigation was carried out at 12, 24, 36 and $48 \mathrm{DAE}$, applying $200 \mathrm{~mL}$ of nutrient solution per pot (50 g of fertilizer diluted in $10 \mathrm{~L}$ of water). Nutrients and their concentrations in the soluble fertilizer were as it follows (Barbosa 2011): $\mathrm{N}=20 \%$; $\mathrm{P}_{2} \mathrm{O}_{5}=20 \% ; \mathrm{K}_{2} \mathrm{O}=20 \% ; \mathrm{Fe}=0.1 \% ; \mathrm{Mn}=0.1 \%$; 
$\mathrm{Zn}=0.1 \% ; \mathrm{Cu}=0.05 \% ; \mathrm{B}=0.02 \% ; \mathrm{Mo}=0.02 \%$. The plants were staked during the experiment. There was no need for pest and disease control treatments.

Phytotechnical evaluations started at 60 DAP. They were carried out according to the phenological scale proposed by Schwab et al. (2015a), for gladiolus. The following traits were evaluated: plant height $(\mathrm{cm})$, number of leaves per plant, marketable harvest point of spikes (d), number of florets per spike, spike length $(\mathrm{cm})$, floret diameter $(\mathrm{cm})$, stem diameter $(\mathrm{cm})$, corm perimeter $(\mathrm{cm})$, number of cormels per plant, corm fresh matter $\left(\mathrm{g} \mathrm{plant}^{-1}\right)$, and dry matter of leaves, spike, corm and cormels ( $\left(\right.$ p plant $\left.^{-1}\right)$.

Evaluations of plant height, number of leaves per plant, marketable harvest point of spikes and stem diameter were carried out in the greenhouse, when the plants reached the R2 phenological stage (flower spikes are ready for harvest; the first three florets at the bottom of the spike show the color of the corolla).

Stem length was measured from the base of the stem in the substrate to the tip of the spike. The marketable harvest point of spikes was calculated as the number of days between corm planting and the R2 stage. Stem diameter was measured twice with a digital caliper, at the insertion of the first floret at the bottom of the spike.

Floret diameter was measured twice per floret with a digital caliper at R3 (i.e., when the corolla of the first and the second floret at the bottom of the spike is open with visible anthers). Since florets open acropetally (i.e., upwards on the rachis), the first two florets at the bottom were assessed.

The spike length and number of florets per spike were determined at R3.6, which is half way through the senescence of the florets on the spike. Spike length was measured from the insertion of the first floret to the tip of the spike.

Corm perimeter, number of cormels per plant, corm fresh matter and dry matter of leaves, spike, corm and cormels were determined at R6 (i.e., when the plant completed the senescence of shoots).

The corms were cleaned and weighed on a semi-analytical balance, to determine the fresh matter, at 155 DAP. Leaves, spike (composed of stem and florets), corm and cormels were separated, packaged in kraft paper bags and dried in an oven with forced air circulation at $65^{\circ} \mathrm{C}$, for $72 \mathrm{~h}$, until constant weight was obtained. Then, the material was weighed on a semi-analytical balance, in order to determine the dry matter.
The data were submitted to analysis of variance, using the Assistat statistical software. The mean values of $\mathrm{GA}_{3}$ applications were compared by the Tukey test at $5 \%$ and $\mathrm{GA}_{3}$ concentrations by regression analysis, with the significance of the coefficients evaluated using a t test at $1 \%$.

\section{RESULTS AND DISCUSSION}

There was no significant interaction between $\mathrm{GA}_{3}$ application methods and concentrations for all the evaluated attributes of the 'White Friendship' cultivar.

The application methods did not affect the plant height, number of leaves per plant, florets per spike, spike length, floret diameter, stem diameter and dry matter of leaves and spike (Table 1). On average, the plants were $128.7 \mathrm{~cm}$ high, produced seven leaves per plant, the flower stem was $0.87 \mathrm{~cm}$ in diameter and the spike length was $44.03 \mathrm{~cm}$.

The average number of florets per spike was 14.2. This trait was not influenced by the application methods (Table 1). According to Paiva et al. (2013), this number may vary from 8 to 18 florets per spike. Oliveira et al. (2012) and Porto et al. (2012), studying the fertilization of the 'White Friendship' cultivar, found 10-14 florets per spike.

For gladiolus, the plant height corresponds to the length of the flower stem. Regardless of the $\mathrm{GA}_{3}$ application method, stem length and diameter were within the standards required by the market. The stems were classified as long $(90 \mathrm{~cm})$ (Tombolato et al. 2010), with spikes of $44.03 \mathrm{~cm}$, on average, corresponding to $48.9 \%$ of the stem length. According to Schwab et al. (2015b), the distribution of florets on the stem becomes aesthetically pleasing when the ratio is above $40 \%$. Stem diameter indirectly indicates stem resistance. Although the $\mathrm{GA}_{3}$ application methods did not affect the stem diameter, it was above the minimum and below the $1.0 \mathrm{~cm}$ required by the market to be classified as extra (Tombolato et al. 2010). Some plants were more than $110.0 \mathrm{~cm}$ long. According to Farias et al. (2013), stems are more resistant to mechanical damage caused by wind, harvest, package and transportation. There was no breakage of stems in this experiment.

According to Sheela (2008), gladiolus plants may also be classified into five groups, according to the floret size: miniature $(<6.4 \mathrm{~cm})$, small 
Table 1. Plant height, number of leaves per plant, marketable harvest point of spikes, number of florets per spike, spike length, floret diameter, stem diameter, corm perimeter, cormels per plant, corm fresh matter and dry matter of leaves, spike, corm and cormels, as a function of $\mathrm{GA}_{3}$ application methods in 'White Friendship' gladiolus cultivar grown in pots.

\begin{tabular}{|c|c|c|c|}
\hline \multirow{2}{*}{ Traits } & \multicolumn{2}{|c|}{$\mathrm{GA}_{3}$ application method } & \multirow{2}{*}{ CV (\%) } \\
\hline & Foliar & Soaking & \\
\hline Plant height $(\mathrm{cm})$ & $130.21 \mathrm{a}^{*}$ & $127.20 \mathrm{a}$ & 6.86 \\
\hline Number of leaves per plant & $6.95 \mathrm{a}$ & $7.21 \mathrm{a}$ & 4.02 \\
\hline Marketable harvest point of spikes (d) & $62.90 \mathrm{a}$ & $60.10 \mathrm{~b}$ & 6.57 \\
\hline Number of florets per spike & $14.42 \mathrm{a}$ & $13.98 \mathrm{a}$ & 8.76 \\
\hline Spike length $(\mathrm{cm})$ & $45.21 \mathrm{a}$ & $42.85 \mathrm{a}$ & 10.31 \\
\hline Floret diameter $(\mathrm{cm})$ & $8.72 \mathrm{a}$ & $8.70 \mathrm{a}$ & 5.57 \\
\hline Stem diameter $(\mathrm{cm})$ & $0.87 \mathrm{a}$ & $0.86 \mathrm{a}$ & 4.35 \\
\hline Corm perimeter $(\mathrm{cm})$ & $19.66 \mathrm{a}$ & $19.08 \mathrm{~b}$ & 4.63 \\
\hline Number of cormels per plant & $64.88 \mathrm{~b}$ & $99.90 \mathrm{a}$ & 11.08 \\
\hline Corm fresh matter $\left(\mathrm{g} \mathrm{plant}^{-1}\right)$ & $52.28 \mathrm{a}$ & $47.07 \mathrm{~b}$ & 11.80 \\
\hline Leaf dry matter $\left(\mathrm{g} \mathrm{plant}^{-1}\right)$ & $10.72 \mathrm{a}$ & $10.62 \mathrm{a}$ & 8.70 \\
\hline Spike dry matter (g plant $\left.{ }^{-1}\right)$ & $3.94 \mathrm{a}$ & $3.80 \mathrm{a}$ & 14.28 \\
\hline Corm dry matter $\left(\mathrm{g}\right.$ plant $\left.{ }^{-1}\right)$ & $15.27 \mathrm{a}$ & $13.68 \mathrm{~b}$ & 7.92 \\
\hline Cormel dry matter (g plant $\left.{ }^{-1}\right)$ & $11.09 \mathrm{a}$ & $7.64 \mathrm{~b}$ & 11.25 \\
\hline
\end{tabular}

(6.4-8.9 $\mathrm{cm})$, decorative $(8.9-11.4 \mathrm{~cm})$, standard or large $(11.4-14.0 \mathrm{~cm})$ and giant $(>14.0 \mathrm{~cm})$. Following this classification, the florets in this study are considered small (almost at the limit of this class), with an average diameter of $8.71 \mathrm{~cm}$.

Flower and ornamental plant wholesale centers, such as the Cooperativa Veiling Holambra and Companhia de Entrepostos e Armazéns Gerais de São Paulo, do not quantitatively classify the floret diameter, possibly because the spikes are sold with closed florets. However, spikes may be sold with some florets open for retail centers near the production site (Barbosa 2011). Thus, spikes with larger florets and smaller distance between them are preferred.

The marketable harvest point of spikes was affected by the $\mathrm{GA}_{3}$ application method. Soaking the corms in a $\mathrm{GA}_{3}$ solution anticipated flowering by 2.8 days, relatively to the foliar spraying (Table 1). According to Chopde et al. (2015), gibberellin may effectively reduce the vegetative growth of plants and induce a reproductive phase. Sajjad et al. (2015) found that soaking corms of the 'Amsterdam' gladiolus cultivar for $24 \mathrm{~h}$, in $100 \mathrm{mg} \mathrm{L}^{-1}$ of $\mathrm{GA}_{3}$, hastened the opening of the first floret on the spike (70.9 d), relatively to the control (77.1 d).

The dry matter of leaves and spikes were not correlated with the $\mathrm{GA}_{3}$ application methods. On average, the foliar dry matter was 10.67 g plant $^{-1}$ and the spike dry matter was 3.87 g plant $^{-1}$. However, GA spraying increased the corm perimeter, corm fresh and dry matter, and cormels dry matter, relatively to the soaking treatment (Table 1). Similar results were also observed by Sudhakar \& Rameshkumar (2012), for the 'White Friendship' cultivar. On the other hand, the soaking method, in this study, increased the number of cormels per plant, if compared to foliar spraying.

The cormel production per corm is one of the most important traits of gladiolus, since it affects the total yield per plant (Patel et al. 2010). All 'White Friendship' plants produced one new corm of excellent commercial quality per each corm planted, for both the $\mathrm{GA}_{3}$ application methods.

The corm size directly affects the spike quality and yield of new corms, as well as their quality in gladiolus. According to Barbosa (2011), in Brazil, corms are commercially classified into seven classes, according to their perimeter $(7 \mathrm{~cm}$ to over $16 \mathrm{~cm})$. In this study, the corms were within the largest class, with average perimeters of $19.66 \mathrm{~cm}$ and $19.08 \mathrm{~cm}$, respectively for the foliar and soaking treatments.

The foliar application of $\mathrm{GA}_{3}$ significantly increased the corm fresh matter $\left(52.28 \mathrm{~g} \mathrm{plant}^{-1}\right)$ and dry matter $\left(15.27 \mathrm{~g} \mathrm{plant}^{-1}\right)$, relatively to the soaking treatment, which produced $47.07 \mathrm{~g} \mathrm{plant}^{-1}$ of fresh matter and $13.68 \mathrm{~g} \mathrm{plant}^{-1}$ of dry matter.

Soon after harvest, which coincides with the natural leaf senescence, corms and cormels undergo a dormancy period, and thus do not sprout, if planted. The absence of visible meristematic growth may be broken by reducing the inhibitor concentration or increasing the antagonist concentration, such as gibberellin. This fact suggests that this phytohormone promotes the germination and sprouting of gladiolus (Barbosa 2011). Direct contact of corms with the $\mathrm{GA}_{3}$ solution produced more cormels per plant than with foliar spraying, probably because it activated dormant buds. However, the corm soaking treatment 
produced less dry matter, in relation to the foliar spraying treatment.

Regardless of the $\mathrm{GA}_{3}$ application method, $\mathrm{GA}_{3}$ concentrations did not affect the following traits: number of leaves per plant $(\bar{y}=7.09 \mathrm{~cm})$, florets
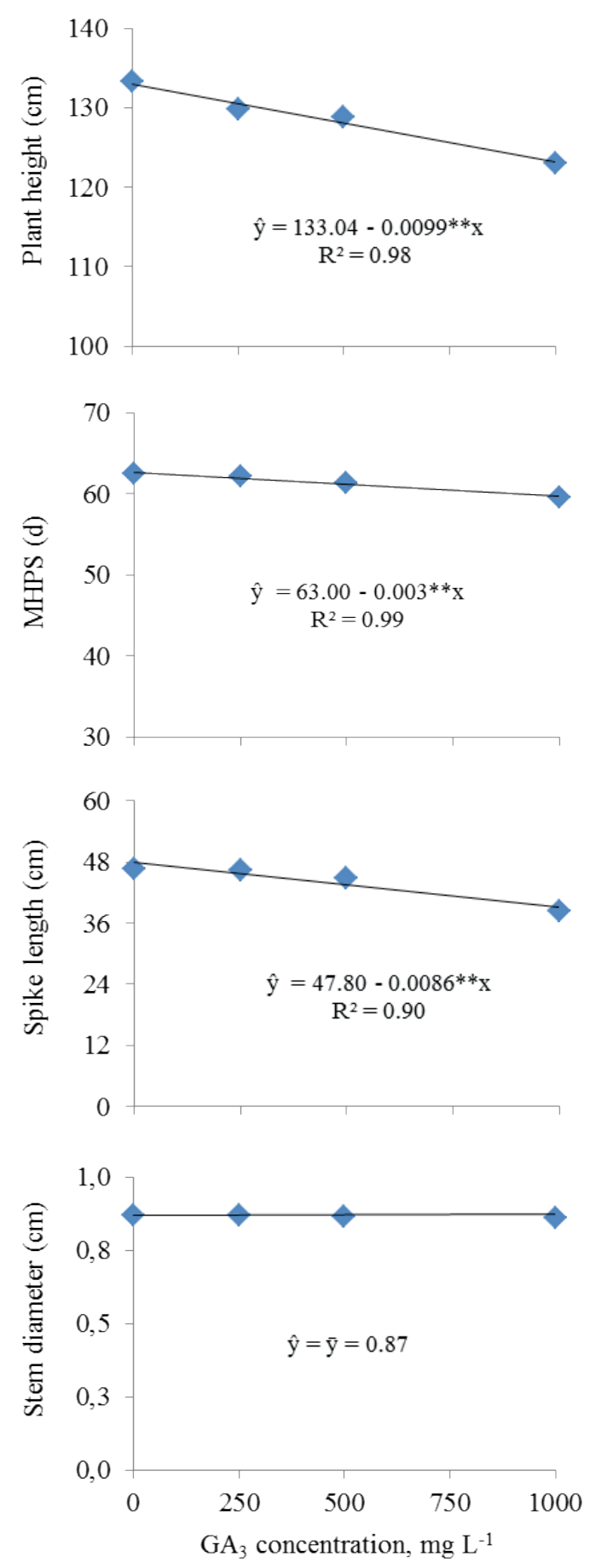

(a)

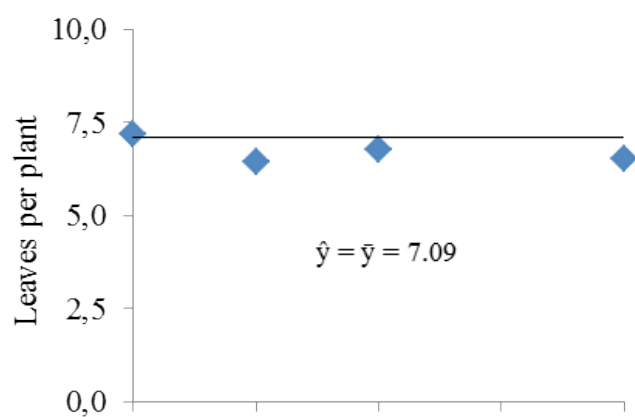

(b)

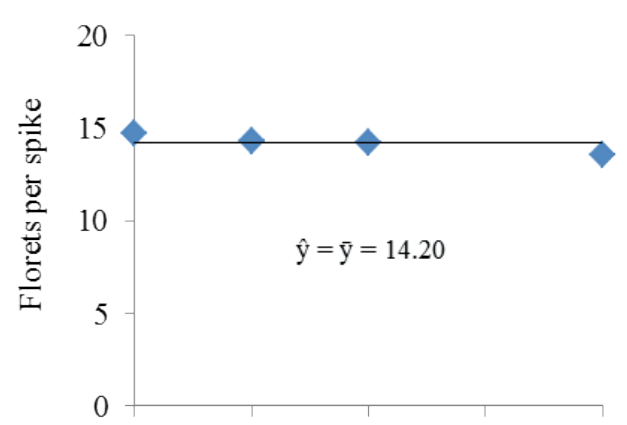

(d)

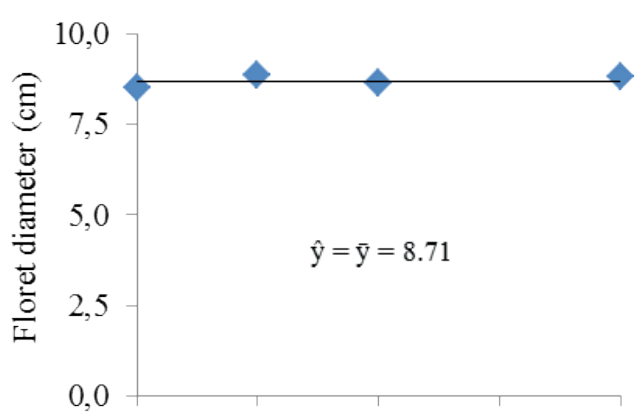

(f)

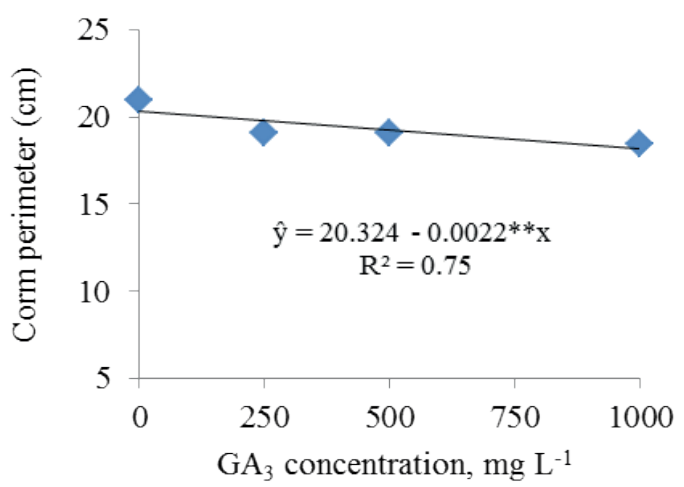

Figure 1. Plant height (a), leaves per plant (b), marketable harvest point of spikes (MHPS) (c), florets per spike (d), spike length (e), floret diameter (f), stem diameter $(\mathrm{g})$ and corm perimeter $(\mathrm{h})$, as a function of various $\mathrm{GA}_{3}$ concentrations applied to the 'White Friendship' gladiolus cultivar grown in pots. ** $\mathrm{p}<0.01$. 
corm perimeter, corm fresh matter and dry matter of spike, corm and cormels.

The highest $\mathrm{GA}_{3}$ concentration reduced plant height by $7.73 \%$ (Figure 1a) and spike length by $17.8 \%$ (Figure 1e), without decreasing its quality, or affecting its commercial value at the Cooperativa Veiling Holambra. Rani et al. (2015) found that $100 \mathrm{mg} \mathrm{L}^{-1}$ of $\mathrm{GA}_{3}$ increased plant height, stem length, spike length, number of florets per plant and floret diameter, in relation to plants without $\mathrm{GA}_{3}$ application. In their study, in addition to the lower doses of $\mathrm{GA}_{3}$ applied via immersion of the

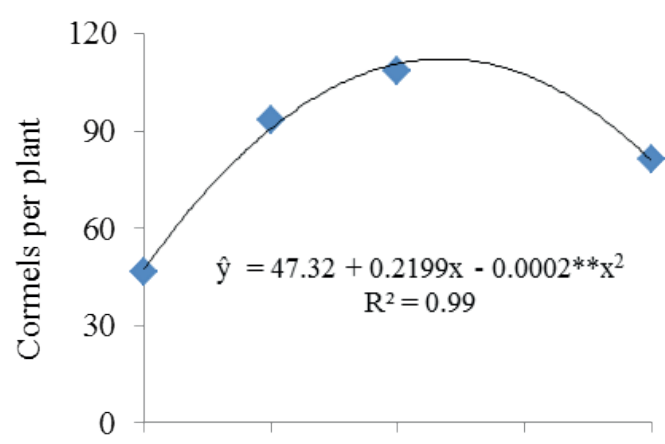

(a)

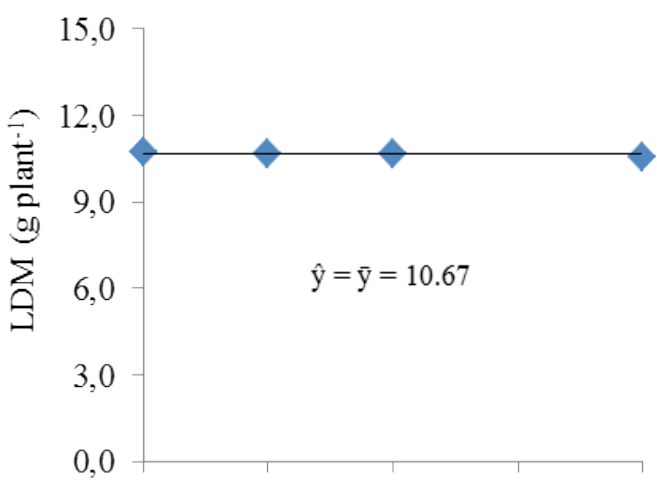

(c)

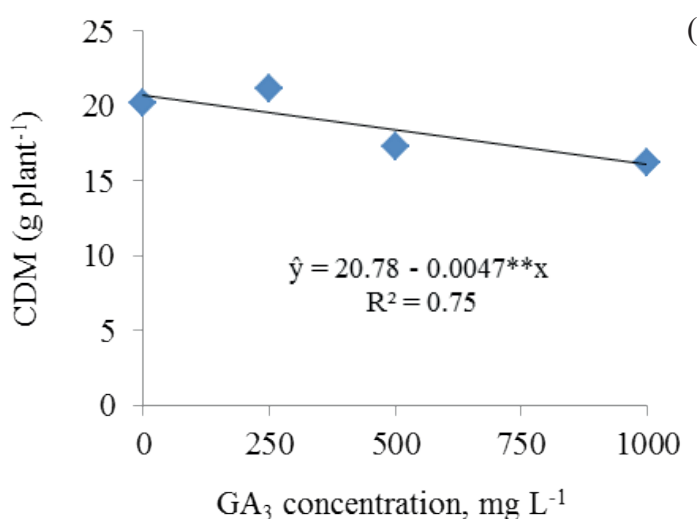

corm for $12 \mathrm{~h}$, they evaluated the 'White Prosperity' gladiolus cultivated in the field, what may explain the difference between the results.

Enhanced gladiolus height and spike length were more pronounced at concentrations up to $200 \mathrm{mg} \mathrm{L}^{-1}$ of GA 3 (Chopde et al. 2015, Sajjad et al. 2015). Gibberellin stimulates cell elongation, thus promoting growth. However, high concentrations, in this study, possibly produced the opposite effect. The marketable harvest point of spikes decreased with increasing $\mathrm{GA}_{3}$ concentrations (Figure 1c). Dogra et al. (2012) and Rani et al. (2015) also observed a

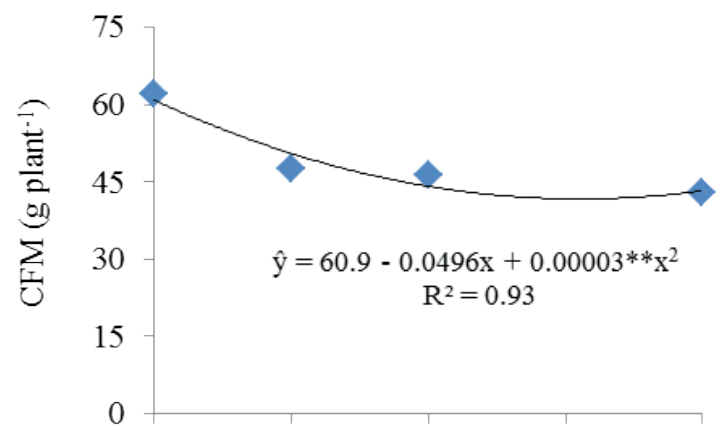

(b)

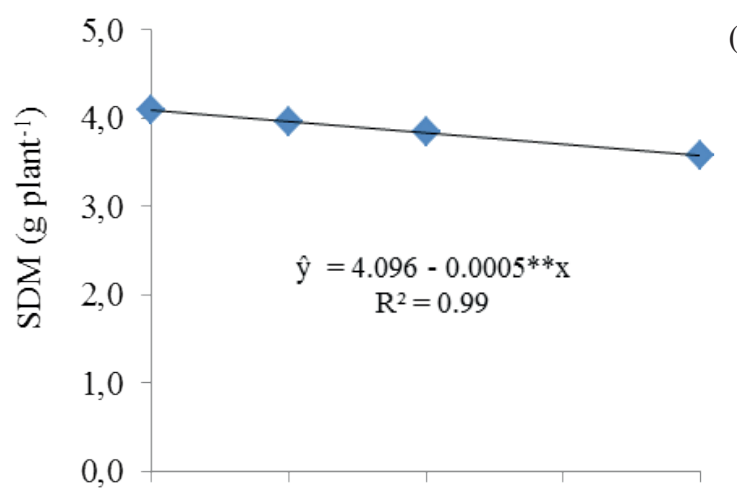

(d)

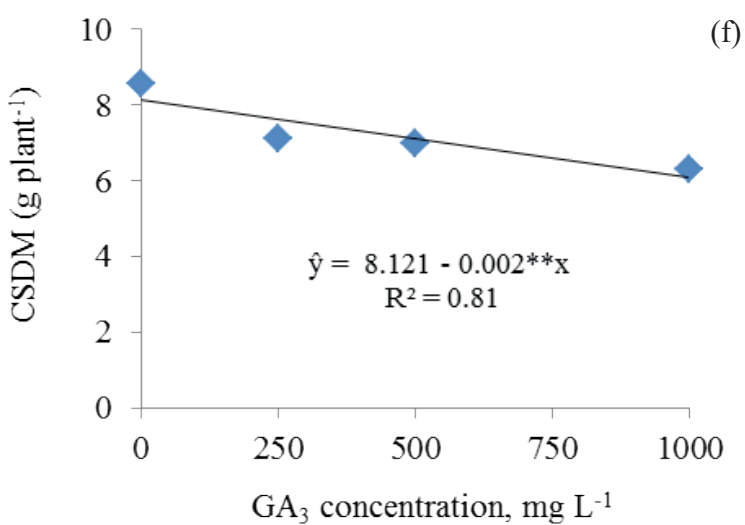

Figure 2. Number of cormels per plant (a), corm fresh matter (CFM) (b), leaf dry matter (LDM) (c), spike dry matter (SDM) (d), corm dry matter (CDM) (e) and cormel dry matter (CSDM) (f), as a function of various $\mathrm{GA}_{3}$ concentrations applied to the 'White Friendship' gladiolus cultivar grown in pots. ${ }^{* *} \mathrm{p}<0.01$. 
reduced number of days to flowering with increasing $\mathrm{GA}_{3}$ concentrations in gladiolus, and Baskaran et al. (2009) reported that $500 \mathrm{mg} \mathrm{L}^{-1}$ of $\mathrm{GA}_{3}$ hastened the gladiolus budding and blooming.

The corm production attributes were correlated with $\mathrm{GA}_{3}$ concentrations. The corm perimeter was reduced by $12.08 \%$, at $1,000 \mathrm{mg} \mathrm{L}^{-1}$ of $\mathrm{GA}_{3}$ (Figure 1h), and the dry matter decreased by $19.44 \%$ (Figure 2e), at $0 \mathrm{mg} \mathrm{L}^{-1}$ of $\mathrm{GA}_{3}$. However, the lowest corm fresh matter production was observed at $826.7 \mathrm{mg} \mathrm{L}^{-1}$ (Figure 2b).

The production of cormels per plant increased with the $\mathrm{GA}_{3}$ concentration up to $549.8 \mathrm{mg} \mathrm{L}^{-1}$, totaling 107.8 units per plant (Figure 2a). In contrast, $1,000 \mathrm{mg} \mathrm{L}^{-1}$ of $\mathrm{GA}_{3}$ reduced the dry matter of cormels by $33.33 \%$, when compared with the control treatment (Figure 2f). Dogra et al. (2012) evaluated the effect of various $\mathrm{GA}_{3}$ concentrations (0-300 $\left.\mathrm{mg} \mathrm{L}^{-1}\right)$ on growth, flowering and corm production of the 'Novalux' gladiolus cultivar, and reported an increased number and dry matter of cormels with increasing concentrations, up to

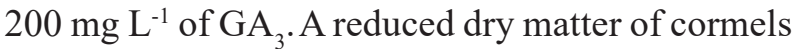
implies in a lower production of commercial corms in the next generations, and consequently lower production of flowers, as corms produce cut flowers (Tombolato 2004).

In commercial floriculture, high yields of cut flowers and corms of excellent quality are a must on highly demanding consumer markets. In general, the $\mathrm{GA}_{3}$ concentration and application method affect the growth and quality of gladiolus spikes and corms. In the present study, the production attributes of the 'White Friendship' cultivar were negatively affected by the application of high concentrations of $\mathrm{GA}_{3}$, thus not being recommended its application. However, further researches with other cultivars are needed to establish a pattern of response under controlled environment.

\section{CONCLUSIONS}

1. High concentrations of $\mathrm{GA}_{3}$ are not recommended for the production of flower spikes and corms of the 'White Friendship' gladiolus cultivar;

2. The corm soaking method anticipates harvest and induces the production of more cormels per plant;

3. Regardless of the application method, $550 \mathrm{mg} \mathrm{L}^{-1}$ of $\mathrm{GA}_{3}$ increases the production of cormels for the 'White Friendship' cultivar.

\section{REFERENCES}

AIER, S. et al. Influence of $\mathrm{GA}_{3}$ and $\mathrm{BA}$ on morphological, phenological and yield attributes in gladiolus cv. Red Candyman. Journal of Agriculture and Veterinary Science, v. 8, n. 6, p. 37-42, 2015.

BARBOSA, J. G. Palma-de-santa-rita (gladiolo): produção comercial de flores e cormos. Viçosa: Ed. UFV, 2011.

BASKARAN, V.; MISRA, R. L.; ABIRAMI, K. Effect of plant growth regulators on corm production in gladiolus. Journal of Horticultural Sciences, v. 4, n. 1, p. 78-80, 2009.

BENSCHOP, M. et al. The global flower bulb industry: production, utilization, research. Horticultural Reviews, v. 36, n. 1, p. 1-115, 2010.

BHUJBAL, G. B.; CHAVAN, N. G.; MEHETRE, S. S. Importance of growth regulator and cold storage treatments for breaking of gladiolus (Gladiolus grandiflorus L.) corm dormancy. The Bioscan, v. 9, n. 2, p. 501-505, 2014.

CHOPDE, N. et al. Growth, yield and quality of gladiolus as influenced by growth regulators and methods of application. Plant Archives, v. 15, n. 2, p. 691-694, 2015.

DOGRA, S.; PANDEY, R. K.; BHAT, D. J. Influence of gibberellic acid and plant geometry on growth, flowering and corm production in gladiolus (Gladiolus grandiflorus) under Jammu agroclimate. International Journal Pharma and Bio Sciences, v. 3, n. 4, p. 1083-1090, 2012.

ESFAHANI, E. N.; EBRAHIMI, H. R.; MIRI, H. R. Effect of gibberellic acid and zinc sulfate on the quality and quantity (Gladiolus grandiflorus) in Isfahan. International Journal of Biology, Pharmacy and Allied Sciences, v. 5, n. 2, p. 156-164, 2016.

FARIAS, A. P. de et al. Produtividade de Heliconia psittacorum x Heliconia pathocircinada cv. Golden Tortch sob diferentes fontes de adubação orgânica. Revista Brasileira de Engenharia Agrícola e Ambiental, v. 17, n. 7, p. 713-720, 2013.

GUPTA, R.; CHAKRABARTY, S. K. Gibberellic acid in plant: still a mystery unresolved. Plant Signaling \& Behavior, v. 8, n. 9, p. e25504, 2013.

JUNQUEIRA, A. H.; PEETZ, M. S. 2012: balanço do comércio exterior da floricultura brasileira. São Paulo: Hórtica Consultoria e Treinamento, 2013.

KERBAUY, G. B. Fisiologia vegetal. 2. ed. Rio de Janeiro: Guanabara Koogan, 2008.

KHAN, F. N.; RAHMAN, M. M.; HOSSAIN, M. M. Effect of benzyladenine and gibberellic acid on dormancy breaking, growth and yield of gladiolus corms over different storage periods. Journal of Ornamental Plants, v. 3, n. 1, p. 59-71, 2013. 
MILLER, W. Current status of growth regulator usage in flower bulb forcing in North America. Floriculture and Ornamental Plant Biotechnology, v. 6, n. 1, p. 35-44, 2012.

MUSHTAQ, S. et al. Studies on the performance of some exotic gladiolus cultivars under rain-fed conditions. International Journal of Modern Agriculture, v. 2, n. 3, p. 108-113, 2013.

OLIVEIRA, J. A. G. et al. Uso de diferentes fertilizantes na produção em vasos de Gladiolus hortulanus L. H. Bailey var. White Friendship, em Ilha Solteira (SP). Revista Brasileira de Horticultura Ornamental, v. 18, n. 2, p. 147-154, 2012.

PAIVA, P. D. O.; FERNANDES, K. D.; CERATTI, M. Gladíolo. In. PAIVA, P. D. O.; ALMEIDA, E. F. A. (Eds.). Produção de flores de corte. Lavras: Ed. da UFLa, 2013. p. 449-469.

PATEL, J. et al. Effect of plant growth regulators on flowering and yield of gladiolus (Gladiolus grandiflorus L.) cv. American Beauty. The Asian Journal of Horticulture, v. 5, n. 2, p. 483-485, 2010.

PORTO, R. A. et al. Adubação nitrogenada no crescimento e produção de gladíolos em Latossolo Vermelho no Cerrado. Agroecossistemas, v. 4, n. 1, p. 2-11, 2012.

PORTO, R. A. et al. Effects of water replacement levels and nitrogen fertilization on growth and production of gladiolus in a greenhouse. Agricultural Water Management, v. 131, n. 1, p. 50-56, 2014.

RAMZAN, F. et al. Pre-planting exogenous application of gibberellic acid influences sprouting, vegetative growth, flowering, and subsequent bulb characteristics of 'AdRem' Tulip. Horticulture, Environment and Biotechnology, v. 55, n. 6, p. 479-488, 2014.
RANI, P. et al. Assessment of growth, floral and yield attributes of gladiolus in response to gibberellic acid treatment. Botany Research International, v. 8, n. 1, p. 1-6, 2015.

SAJJAD, Y. et al. Pre-plant soaking of corms in growth regulators influences the multiple sprouting, floral and corm associated traits in Gladiolus grandiflorus L. Journal of Agricultural Science, v. 7, n. 9, p. 173-181, 2015.

SCHWAB, N. T. et al. A phenological scale for the development of gladiolus. Annals of Applied Biology, v. 166, n. 3, p. 496-507, 2015a.

SCHWAB, N. T. et al. Parâmetros quantitativos de hastes florais de gladíolo conforme a data de plantio em ambiente subtropical. Pesquisa Agropecuária Brasileira, v. 50, n. 10, p. 902-911, 2015b.

SHEELA, V. L. Flowers for trade. New Delhi: New India Publishing Agency, 2008.

SUDHAKAR, M.; RAMESHKUMAR, S. Effect of growth regulators on growth, flowering and corm production of gladiolus (Gladiolus grandiflorus L.) cv. White friendship. Indian Journal of Plant Science, v. 1, n. 2, p. 133-136, 2012.

TAIZ, L.; ZEIGER, E. Fisiologia vegetal. 5. ed. Porto Alegre: Artmed, 2013.

TOMBOLATO, A. F. C. Cultivo comercial de plantas ornamentais. Campinas: Instituto Agronômico, 2004.

TOMBOLATO, A. F. C. et al. Bulbosas ornamentais no Brasil. Revista Brasileira de Horticultura Ornamental, v. 16, n. 2, p. 127-138, 2010.

VIEIRA, M. R. S. da et al. Use of gibberellin in floriculture. African Journal of Biotechnology, v. 9, n. 54, p. 9118-9121, 2010. 